\title{
Nerve growth factor-mediated inhibition of apoptosis post-caspase activation is due to removal of active caspase-3 in a lysosome-dependent manner
}

\author{
K Mnich $^{1,2,4}$, LA Carleton ${ }^{1,4}$, ET Kavanagh ${ }^{1}$, KM Doyle ${ }^{3}$, A Samali ${ }^{1}$ and AM Gorman ${ }^{\star, 1}$
}

Nerve growth factor (NGF) is well characterised as an important pro-survival factor in neuronal cells that can inhibit apoptotic cell death upstream of mitochondrial outer membrane permeabilisation. Here we addressed the question of whether NGF can also protect against apoptosis downstream of caspase activation. NGF treatment promoted a rapid reduction in the level of the p17 subunit of active caspase-3 in PC12 cells that had been induced to undergo apoptosis by various cytotoxins. The mechanism involved TrkA-dependent activation of extracellular signal-regulated kinase (ERK1/2) but not phosphatidylinositol 3-kinase (PI3K)/Akt, and de novo protein synthesis. Involvement of inhibitor of apoptosis proteins (IAPs) and proteasomal degradation were ruled out. In contrast, inhibition of lysosome function using chloroquine and concanamycin A reversed NGF-induced removal of p17. Moreover, in NGF-treated cells, active caspases were found to be localised to lysosomes. The involvement of macroautophagy and chaperone-mediated autophagy were ruled out. Taken together, these findings suggest an anti-apoptotic mechanism by which NGF induces removal of active caspase-3 in a lysosome-dependent manner.

Cell Death and Disease (2014) 5, e1202; doi:10.1038/cddis.2014.173; published online 1 May 2014

Subject Category: Neuroscience

Apoptosis is important in the elimination of unwanted or damaged cells in multicellular organisms. A detailed understanding of the apoptotic pathway commitment point is crucial for the development of new therapeutic strategies to combat undesirable apoptosis that occurs in certain degenerative diseases and in acute injury, such as ischemia. ${ }^{1}$ Central to apoptosis is the activation of caspase proteases that drive cellular disassembly. ${ }^{2}$ In healthy cells, caspases are maintained as inactive zymogens. One of the main mechanisms of caspase activation is through mitochondrial outer membrane permeabilisation (MOMP). ${ }^{3}$ Upon MOMP, cytochrome $c$ translocates into the cytosol to initiate formation of the apoptosome complex, leading to proximity-induced auto-activation of initiator caspase-9. ${ }^{4}$ Once activated, caspase- 9 cleaves and activates executioner caspases, such as caspase- 3 and $-7 .{ }^{5}$

MOMP and cytochrome $c$ release are commonly regarded as the commitment point in apoptosis, such that once it occurs the cell is irretrievably destined to die. Regulation of apoptosis occurs mainly upstream of mitochondrial changes, through the altered expression and/or posttranslational modification of pro- and anti-apoptotic Bcl-2 family members. ${ }^{6,7}$ However, there also exist mechanisms for the regulation of caspases downstream of mitochondria. The E3 ubiquitin ligase XIAP can directly interact with active caspase- $-9,-3$ and -7 , inhibiting their enzymatic activity, although it remains controversial whether active caspases can be targeted for proteasomal degradation by this or other inhibitor of apoptosis proteins (IAPs). ${ }^{8-10}$

Nerve growth factor (NGF) is a potent pro-survival factor for sub-populations of neuronal cells during development and in postmitotic neurons. ${ }^{11}$ Withdrawal of NGF from NGF-dependent neurons results in apoptosis. ${ }^{12}$ The pro-survival effects of NGF are mediated by the receptor tyrosine kinase TrkA. We have previously shown that NGF activation of phosphatidylinositol 3-kinase (PI3K)/Akt signalling can protect cells upstream of MOMP through regulation of pro-apoptotic Bcl-2 family members. ${ }^{13}$

Here, we explored whether NGF could also interfere with apoptosis downstream of MOMP, that is, post-caspase activation, using the NGF-responsive cell line PC12. We show for the first time that NGF can protect cells post-caspase

\footnotetext{
${ }^{1}$ Apoptosis Research Centre, School of Natural Sciences, National University of Ireland, Galway, Ireland; ${ }^{2}$ Nencki Institute of Experimental Biology, Polish Academy of Sciences, Warsaw, Poland and ${ }^{3}$ School of Medicine, National University of Ireland, Galway, Ireland

*Corresponding author: AM Gorman, Apoptosis Research Centre, School of Natural Sciences, National University of Ireland, Galway, Ireland. Tel: +353 91 492417; Fax: +353 91 495504; E-mail: Adrienne.gorman@ nuigalway.ie

${ }^{4}$ These authors contributed equally to this work.

Keywords: apoptosis; autophagy; caspases; lysosomes; nerve growth factor (NGF)

Abbreviations: BSA, bovine serum albumin; CHAPS, 3-[(3-cholamidopropyl)-dimethylammonio]-1-propanesulfonate; CMA, chaperone-mediated autophagy; ConA, concanamycin A; CQ, chloroquine; DMEM, Dulbecco's Modified Eagle's medium; DN, dominant negative; DTT, dithiothreitol; EGF, epidermal growth factor; EGTA, ethylene glycol tetraacetic acid; ER, endoplasmic reticulum; ERK, extracellular signal-regulated kinase; HEPES, N-2-hydroxyethyl-piperazine-N-2-ethanesulphonic acid; Hsc70, heat-shock cognate protein 70; IAP, inhibitor of apoptosis protein; KD, knock down; LAMP, lysosome-associated membrane protein; MOMP, mitochondrial outer membrane permeabilisation; NGF, nerve growth factor; NP-40, nonidet P-40; PARP, poly-ADP ribose polymerase; PI3K, phosphatidylinositol 3-kinase; PLC, phospholipase C; PLL, poly-L-lysine; PMSF, phenylmethylsulphonyl fluoride; PS, phosphatidylserine; SDS, sodium dodecyl sulphate; TG, thapsigargin; TMRE, tetramethylrhodamine, ethyl ester; zVAD-fmk, carbobenzoxy-valyl-alanyl-aspartyl-[O-methyl]-fluoromethylketone

Received 01.8.13; revised 18.2.14; accepted 19.2.14; Edited by A Verkhratsky
} 
activation via extracellular signal-regulated kinase (ERK)dependent removal of active caspases to lysosomes.

\section{Results}

NGF promotes long-term survival of PC12 cells downstream of caspase-3 activation. To establish a suitable time for studying NGF treatment post-caspase activation, we investigated the kinetics of thapsigargin (TG)-induced apoptosis in PC12 cells. Loss of $\Delta \Psi_{\mathrm{m}}$ was observed by $18 \mathrm{~h}$ as judged by reduction in TMRE staining (Figure 1a). Activation of caspase- $9,-3$ and -7 was detectable by $16-18 \mathrm{~h}$, at which time the processed fragments were visible (Figure 1b). This was temporally associated with poly-ADP ribose polymerase (PARP) cleavage (Figure 1b). Annexin $\mathrm{V}$ labelling, another indicator of caspase activation, was observed after $20 \mathrm{~h}$ of TG treatment (Figure 1c).

To determine the effect of NGF addition at times pre-caspase and post-caspase activation, TG-treated PC12 cells were treated with NGF $2 \mathrm{~h}$ before TG or 18 or $23.5 \mathrm{~h}$ after $T G$, and DEVDase activity was measured. Pre-treatment with NGF provided robust inhibition of DEVDase activity (Figure 2a). Unexpectedly, NGF added at $18 \mathrm{~h}$ after TG also led to robust reduction in DEVDase activity (Figure 2a). This effect was not observed with NGF addition $23.5 \mathrm{~h}$ after TG. Furthermore, addition of NGF at 18 , but not $23.5 \mathrm{~h}$, post-TG treatment caused almost complete reduction in the levels of active caspase-3 (Figure 2b), indicating that the reduced DEVDase activity was due to removal of active caspases. NGF addition post-caspase activation caused a rapid loss in the active subunits of both executioner caspase- 3 and -7 and initiator caspase-9, which was accompanied by a reduction in PARP cleavage (Figure 2c).

To determine whether this effect of NGF is specific to TG-induced apoptosis, cells were treated with other apoptosis inducers, etoposide (topoisomerase II inhibitor causing DNA damage), staurosporine (general protein kinase $\mathrm{C}$ inhibitor) and tunicamycin (inhibitor of $\mathrm{N}$-linked glycosylation inducing endoplasmic reticulum (ER) stress). Addition of NGF postcaspase activation resulted in reduction of $p 17$ levels in all cases (Figure 2d), demonstrating that the effect of NGF on active caspases is not limited to TG or to ER stress-induced apoptosis.

We performed clonogenic assays to examine the effect of NGF treatment post-caspase activation on long-term survival of cells. Treatment with TG alone caused a $55 \%$ decrease in clonogenic survival compared with untreated cells (Figure 3a). This was completely reversed upon pre-treatment with NGF. Surprisingly, addition of NGF $18 \mathrm{~h}$ after TG also completely restored clonogenic survival, while treatment with NGF $23.5 \mathrm{~h}$ after TG treatment provided no protection (Figure 3a). These data suggest that NGF can rescue cells post-caspase activation. However, an alternative interpretation is that cells that display long-term survival had not yet initiated the death programme and did not contain active caspases. To isolate cells with active caspases, we used an Annexin V Microbead kit. As phosphatidylserine (PS) exposure is dependent on caspase activity, the isolated population should include only cells containing active caspases. ${ }^{14-16}$ Following isolation, the PS-exposing cells were divided into two samples that were a

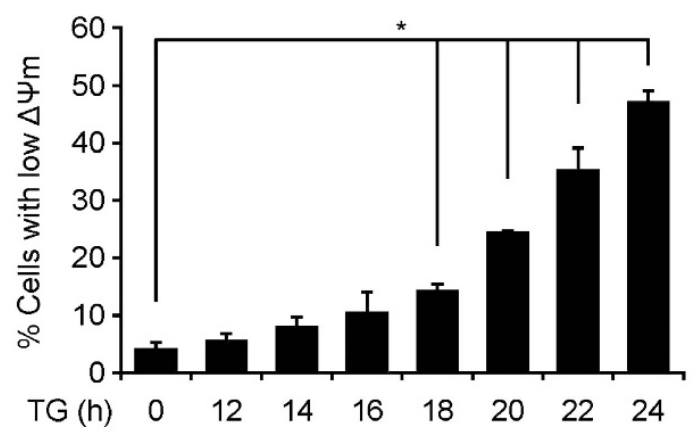

b

$$
\text { TG (h) }
$$

$\begin{array}{llllllll}- & 12 & 14 & 16 & 18 & 20 & 22 & \mathrm{kDa}\end{array}$

Pro-caspase-9 - - - $-\longrightarrow 47$ Cleaved caspase-9- $-\div-\square=\frac{47}{40 / 38}$

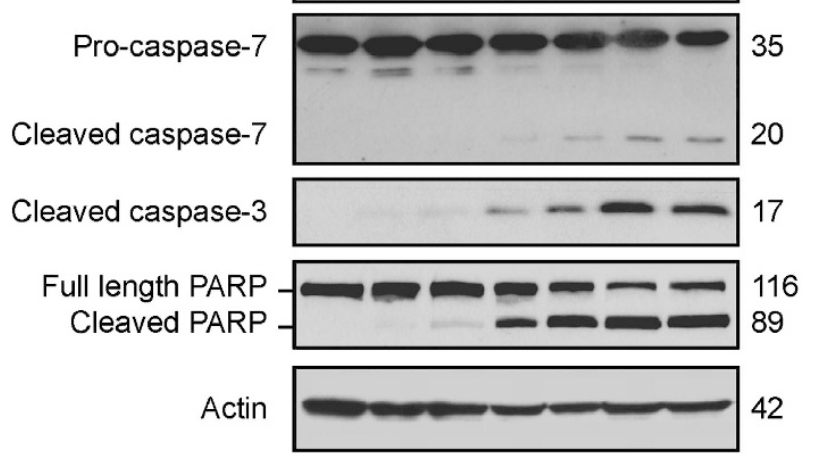

c

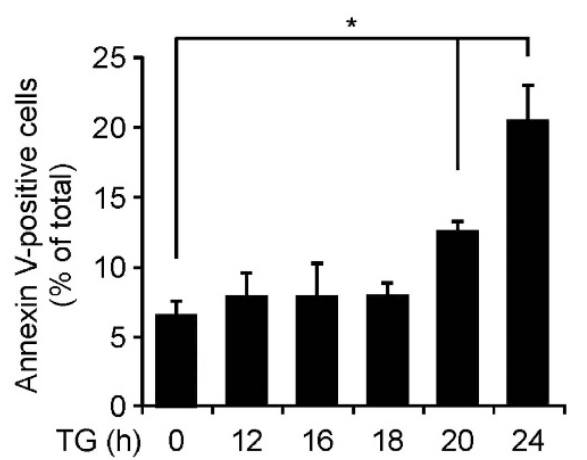

Figure 1 Kinetics of apoptosis-related changes in TG-treated PC12 cells. PC12 were treated with $1 \mu \mathrm{M}$ TG for the indicated times. (a) Loss of mitochondrial transmembrane potential $(\Delta \Psi \mathrm{m})$ was analysed using TMRE stain. Cells were harvested by trypsinisation and treated with $100 \mathrm{nM}$ TMRE for $30 \mathrm{~min}$ in the dark. Fluorescence of the cells was measured at $582 \mathrm{~nm}$ by flow cytometry. Cells with low TMRE fluorescence were expressed as a percentage of the total cells. The results shown correspond to the mean \pm SEM of three separate experiments. ${ }^{*} P<0.01$ using Bonferroni post hoc test. (b) TG-induced activation of caspases was analysed by western blotting using antibodies to caspase- $9,-7,-3$ and PARP. Actin was used as a loading control. (c) Externalisation of PS was analysed using Annexin V-FITC labelling. Cells were harvested by trypsinisation, allowed to recover for $15 \mathrm{~min}$ and then resuspended in calcium buffer containing Annexin V-FITC. The fluorescence of the cells was measured at $495 \mathrm{~nm}$ by flow cytometry. ${ }^{*} P<0.005$ using LSD post hoc test

reseeded for a clonogenic assay, one of which was treated with NGF every 2 days and the other untreated. After 7 days, we counted the numbers of colonies containing $>10$ cells and cells with neurites (as prolonged treatment of $\mathrm{PC} 12$ cells with NGF causes them to differentiate and extend neurites ${ }^{17}$ ). The NGF-treated cells exhibited a $2.4 \pm 0.35$-fold increase in 


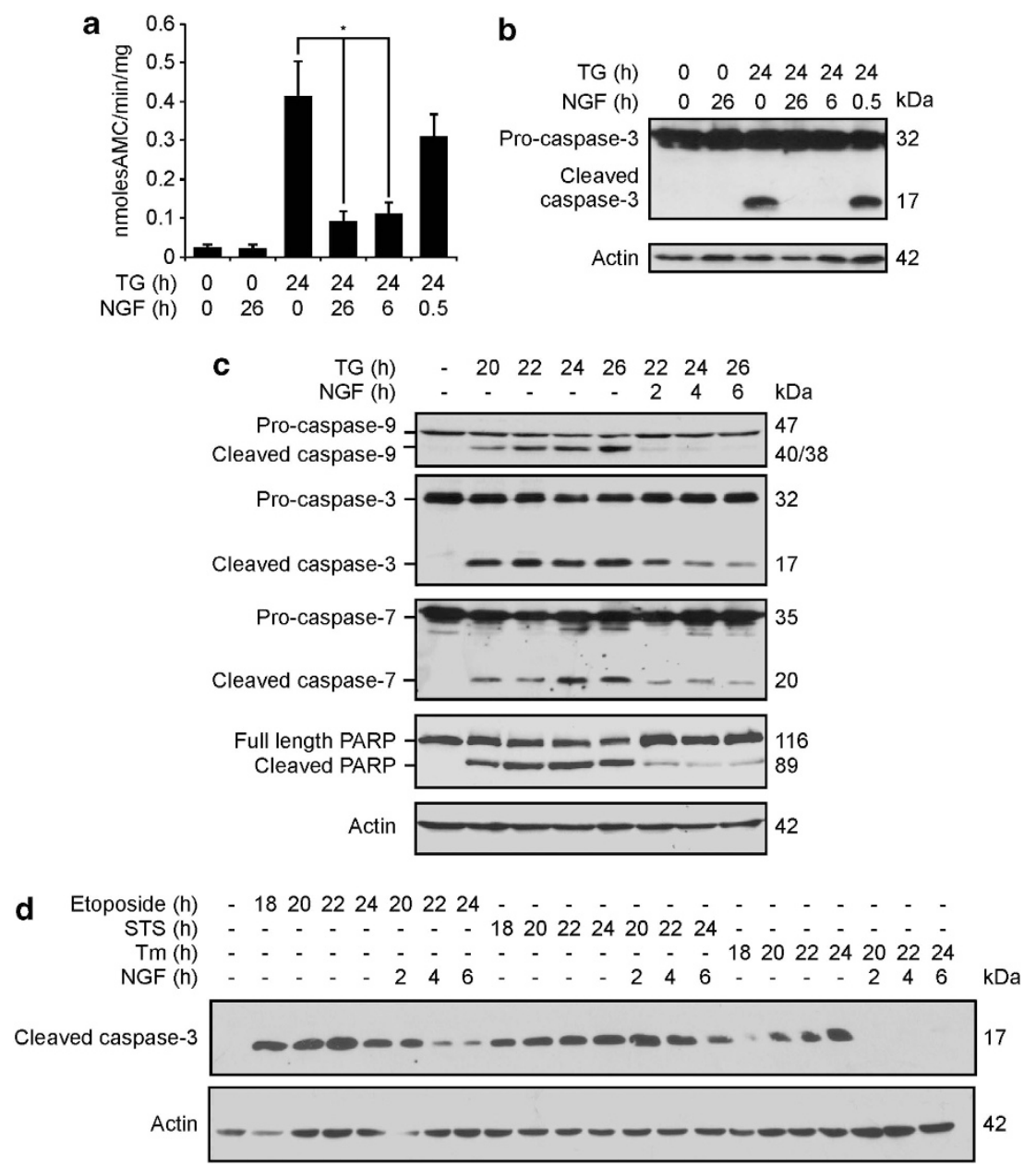

Figure 2 NGF induces loss of active caspase-3. PC12 cells were exposed to $1.5 \mu \mathrm{M} \mathrm{TG}$ in the presence or absence of NGF, which was added either $2 \mathrm{~h}$ before TG or 18 or $23.5 \mathrm{~h}$ after TG. Cells were harvested at $24 \mathrm{~h}$ after TG treatment. (a) DEVDase activity was measured. The times shown on the graph indicate the total duration of TG or NGF treatment. ${ }^{*} P<0.05$ using Bonferroni's post hoc test. (b) Whole-cell lysates were analysed by western blotting using anti-caspase-3. Actin was used as a loading control. (c) PC12 cells were treated with $1.5 \mu \mathrm{M}$ TG for $20 \mathrm{~h}$, followed by treatment with NGF for indicated periods of time. Whole-cell lysates were analysed by western blotting using antibodies against caspase-9, $-7,-3$ and PARP. Actin was used as a loading control. The data are representative of three separate experiments. (d) PC12 cells were treated with $40 \mu \mathrm{M}$ etoposide, $500 \mathrm{nM}$ staurosporine (STS) or $1.5 \mu \mathrm{M}$ tunicamycin (Tm) for $18 \mathrm{~h}$, followed by treatment with NGF. Cells were harvested $24 \mathrm{~h}$ after addition of cytotoxins. Western blotting was performed using an antibody against cleaved caspase-3. Actin was shown as a loading control. Results are representative of three separate experiments

survival compared with those without NGF (Figure 3b). This experiment was repeated six times with a range of 850-10 000 Annexin V-selected cells seeded for individual experiments. For example: in one representative experiment, 850 Annexin $\mathrm{V}$-selected cells were seeded. Of these, 564 were trypan blue positive, and thus beyond recovery, and the remaining 286 cells had the potential to recover. The number of surviving colonies ranged from 6 to 100 in the absence of NGF and from 19 to 209 in the presence of NGF with a fold increase ranging from 1.6- to 4.2-fold. PS externalisation to the outer plasma membrane is a well-known characteristic of apoptosis. However, several publications show that PS externalisation is not necessarily due to caspase activity and that it can be a reversible event. ${ }^{18}$ Therefore, we further characterised the Annexin V-selected cells to determine their mitochondrial status and whether they had active caspases. TMRE staining revealed that $46.5 \%$ of TG-treated cells (whole population) had high $\Delta \Psi \mathrm{m}$, in contrast to just $0.95 \%$ of Annexin V-selected TG-treated cells (Figures $3 c$ and $d$ ). Immunofluorescence showed that all of the Annexin V-selected cells contained active caspase-3 (Figure $3 e$ ). These data confirm that the selection of the TG-treated cells using Annexin $\mathrm{V}$ is a valid surrogate for caspase activity in these cells.

To ask whether NGF could promote repair of the $\Delta \Psi \mathrm{m}$ in the cells, we used the whole cell population because of low yield with Annexin V selection. Cells were treated with TG for $20 \mathrm{~h}$, at which time there is loss of $\Delta \Psi \mathrm{m}$ and cytochrome $c$ release from the mitochondria, ${ }^{13}$ reseeded into fresh media with or without NGF and allowed to adhere for 6 or $20 \mathrm{~h}$. Tetramethylrhodamine, ethyl ester (TMRE) staining revealed a significant increase in the proportion of cells with increased $\Delta \Psi \mathrm{m}$ after $20 \mathrm{~h} \mathrm{NGF}$ treatment compared with cells left to recover without NGF (Figure $3 f$ ). Recovery of $\Delta \Psi \mathrm{m}$ was time dependent, with a larger number of cells exhibiting high $\Delta \Psi \mathrm{m}$ after $20 \mathrm{~h}$ compared with 6 - $\mathrm{h}$ recovery (Figure $3 \mathrm{~g}$ ). Although this recovery in $\Delta \Psi \mathrm{m}$ was higher in the NGF-treated population, it was also observed in the absence of NGF (Figure $3 \mathrm{~g}$ ). These data support the hypothesis that 
NGF promotes long-term recovery of cells post-caspase activation.

Role of TrkA/ERK signalling. To investigate the signalling pathway that is involved in the removal of active caspase-3,
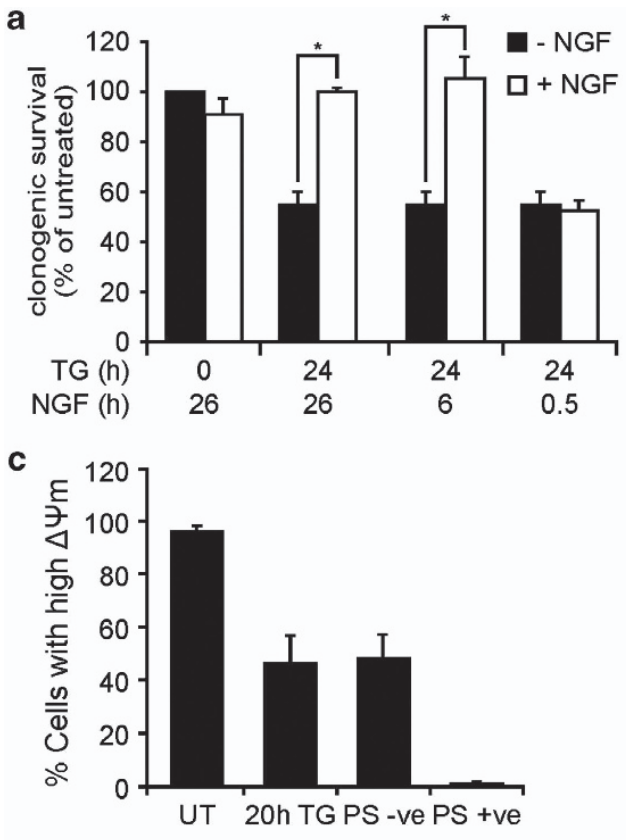

e
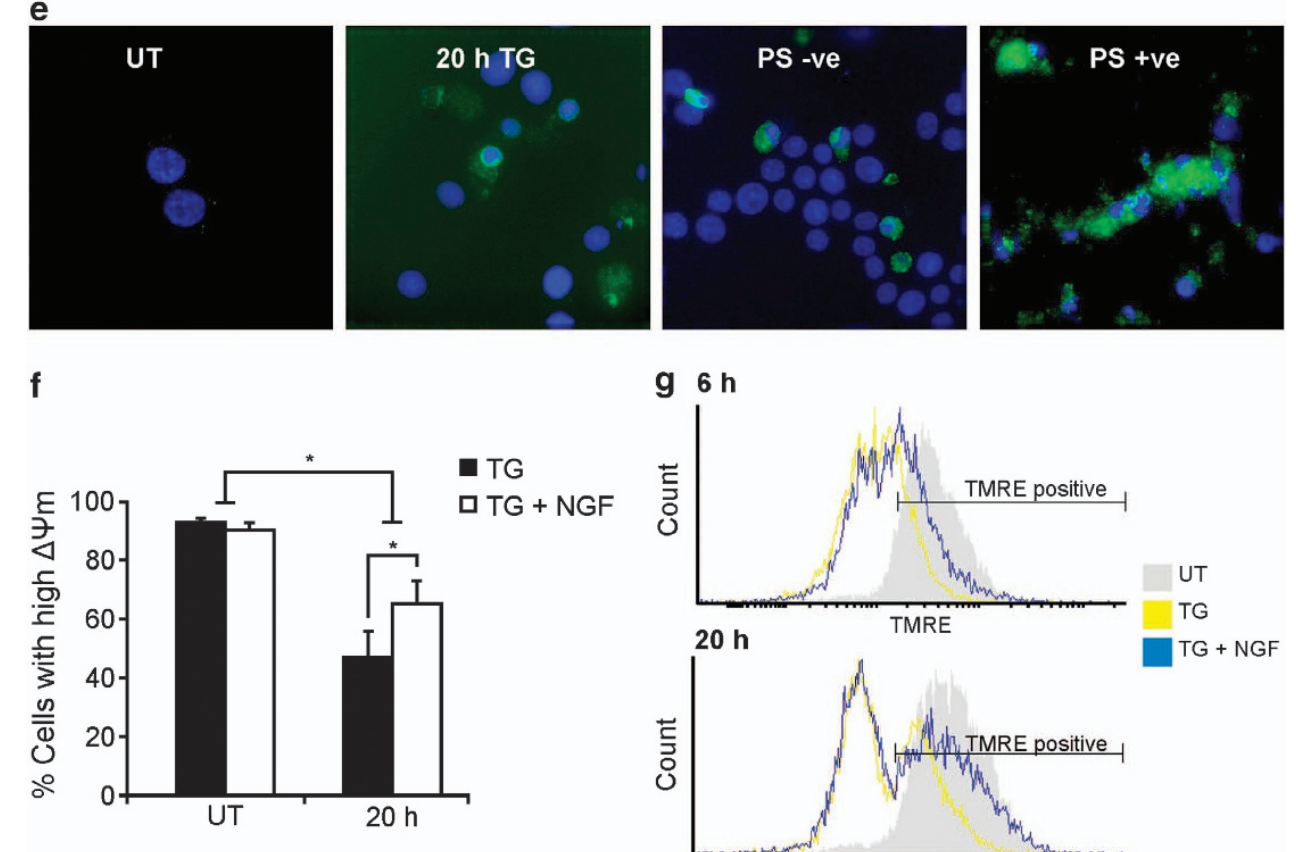

g $6 \mathrm{~h}$

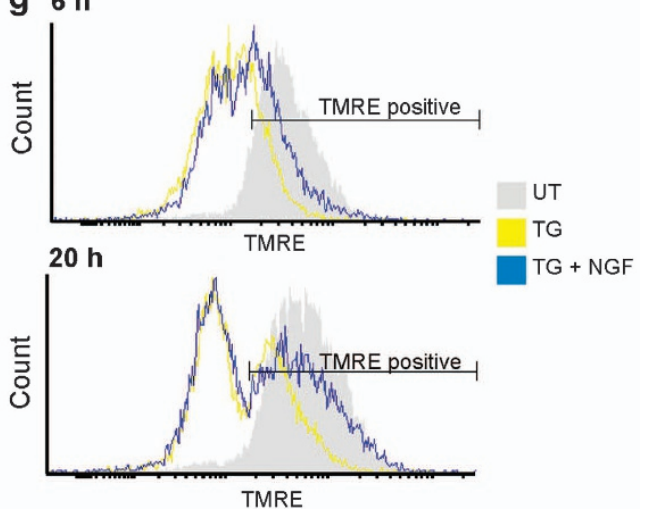

we used several pharmacological inhibitors. The TrkA receptor inhibitor $\mathrm{K}_{2} 52 \mathrm{a}^{19}$ revealed that this effect is dependent on TrkA signalling (Figure 4a).

TrkA can activate PI3K/Akt, MEK/ERK1/2 and phospholipase C (PLC) signalling pathways. ${ }^{20,21}$ Therefore, TG-treated

b
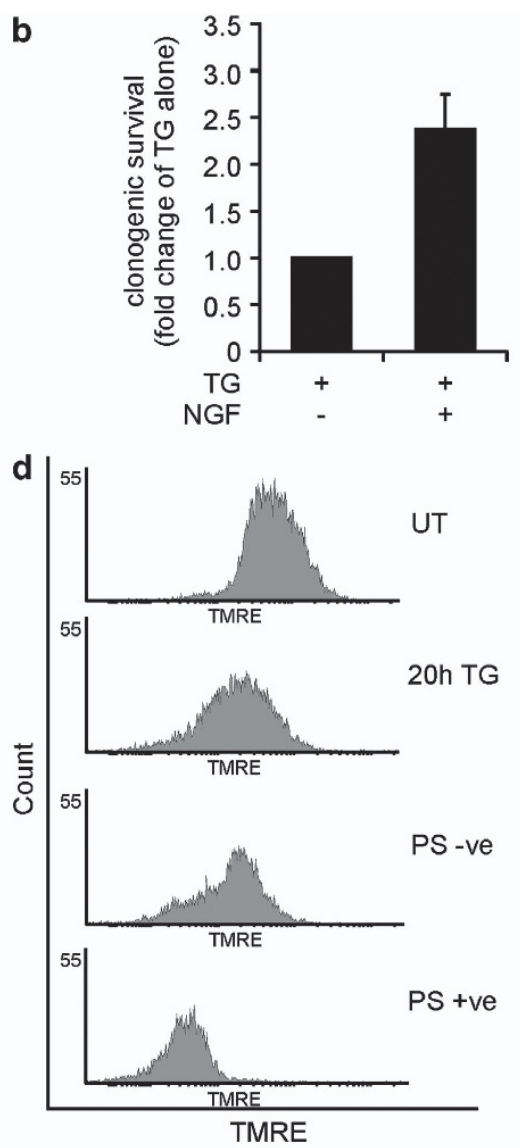

TMRE 
PC12 cells were incubated with LY294002 (PI3K inhibitor), U73122 (PLC inhibitor) or UO126 (MEK1/2 inhibitor), before NGF addition. Neither PI3K nor PLC inhibition affected NGF-induced removal of p17 (Figures $4 b$ and c). In contrast, ERK1/2 inhibition partially restored the level of $p 17$ (Figure 4d). Together, these data indicate an involvement of ERK $1 / 2$ signalling and a lack of involvement of PI3K in NGF-induced regulation of active caspase-3.
The duration of ERK activation can regulate various cell fate decisions. For example, sustained phosphorylation by NGF induces PC12 cell differentiation, ${ }^{17}$ while transient ERK phosphorylation by epidermal growth factor (EGF) stimulates their proliferation. ${ }^{22}$ To determine whether transient ERK activation could promote removal of active caspase-3, we compared the effect of EGF and NGF. NGF induced sustained ERK1/2 phosphorylation while that induced by

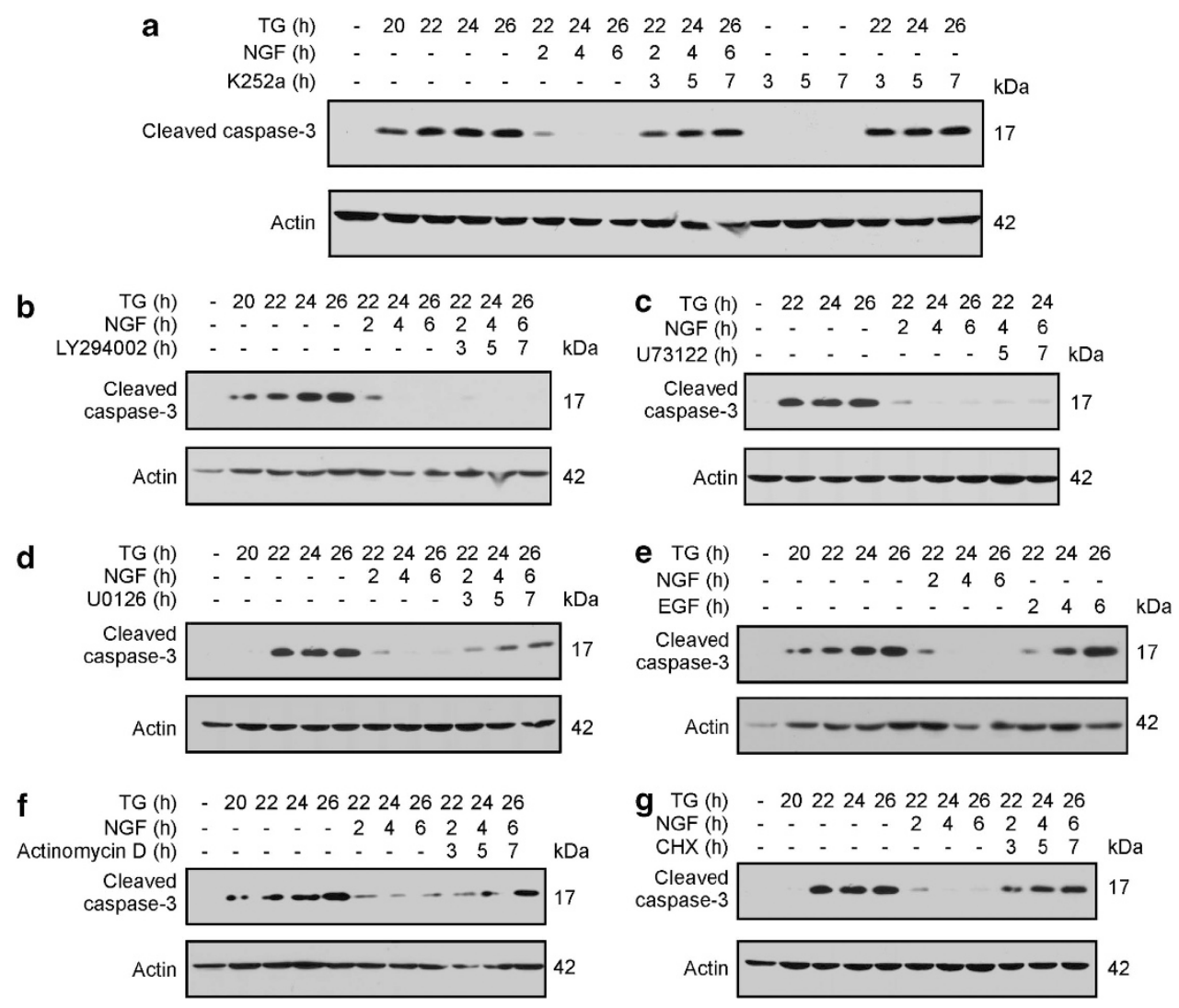

Figure 4 NGF-induced removal of p17 involves TrkA-dependent activation of ERK1/2 and de novo protein synthesis. PC12 cells were treated with $1.5 \mu \mathrm{M} \mathrm{TG}$ for $19 \mathrm{~h}$, followed by incubation of cells with (a) $100 \mathrm{nM} \mathrm{K252a,} \mathrm{(b)} 40 \mu \mathrm{M} \mathrm{LY} 294002$, (c) $2 \mu \mathrm{g} / \mathrm{ml} \mathrm{U73122} \mathrm{or} \mathrm{(d)} 10 \mu \mathrm{M}$ U0126 for $1 \mathrm{~h}$ before addition of NGF. Cells were harvested at $20-26 \mathrm{~h}$ as indicated, and the levels of p17 were analysed by western blotting using antibody against cleaved caspase-3. Actin was used as a loading control. Images are representative of three separate experiments. (e) PC12 cells were treated with $1.5 \mu \mathrm{M}$ TG for $20 \mathrm{~h}$ followed by treatment with NGF or $150 \mathrm{ng} / \mathrm{ml}$ EGF. The cells were harvested at 20-26 h as indicated, and the changes in p17 subunit levels was measured by western blotting for cleaved caspase-3. Actin was used as a loading control. Cells were treated as above either with or without (f) $10 \mu \mathrm{g} / \mathrm{ml}$ actinomycin D or (g) $10 \mu \mathrm{g} / \mathrm{ml}$ cycloheximide for $1 \mathrm{~h}$ before addition of NGF. Cells were harvested, and western blotting was performed as described above. Results shown are all representative of three separate experiments

Figure 3 NGF induces the long-term survival of cells with active caspase-3. (a) PC12 cells were treated with $1.5 \mu \mathrm{M} \mathrm{TG}$ for $24 \mathrm{~h}$. NGF was added $2 \mathrm{~h}$ before TG treatment or at 18 or $23.5 \mathrm{~h}$ after TG treatment. Cells were then replated and allowed to proliferate into colonies for 14 days. Colonies containing $>50$ cells were counted. Clonogenic survival was expressed as a \% of untreated cells \pm S.E.M. from three separate experiments. ${ }^{*} P<0.05$ using Bonferroni's post hoc test. (b) PC12 cells were treated with $1 \mu \mathrm{M}$ TG for $20 \mathrm{~h}$. Cells with externalised PS were labelled using Annexin V MicroBeads and isolated in a magnetic field from non-apoptotic cell population. The isolated population was reseeded, and one sample was treated with NGF every second day and the other was left untreated. Colonies containing $>10$ cells or cells containing neurites were counted to determine the number of surviving cells. The data shown are average of six separate experiments \pm S.E.M. Values are normalised to the TG-treated surviving cells. (c) During the isolation of cells exposing PS, samples were taken of cells treated with or without TG for $20 \mathrm{~h}$ before being subjected to the magnetic field. Of the TG-treated cells, samples of cells that did not bind to the magnetic column (PS -ve) and of cells that bound to the magnetic column (PS + ve) were taken. The $\Delta \Psi \mathrm{m}$ was then analysed using TMRE and flow cytometry, and the percentage of cells with high $\Delta \Psi \mathrm{m}$ was quantified. The values are the mean \pm S.E.M. of three separate experiments. (d) Representative histograms of the TMRE analysis of cells sampled in panel (c). (e) Immunofluorescence analysis of active caspase-3 in cells sampled in panel (c). The nuclei were stained using DAPI and the p17 levels are visualised using the cleaved caspase-3 antibody. Results are representative of three separate experiments. (f and $\mathbf{g}$ ) PC12 cells were treated with $1.5 \mu \mathrm{M} \mathrm{TG}$ for $18 \mathrm{~h}$, then trypsinised and reseeded into fresh media with or without $100 \mathrm{ng} / \mathrm{ml}$ NGF. The cells were then allowed to recover for the indicated times and the loss of $\Delta \Psi \mathrm{m}$ was analysed using TMRE and flow cytometry. The percentage of cells with high $\Delta \Psi \mathrm{m}$ following $20 \mathrm{~h}$ of recovery is shown in panel (f). The data are the mean of three repeats \pm S.E.M. ${ }^{*} P<0.05$ using analysis of variance with LSD post hoc test. An overlay of the histograms of untreated cells (grey), cells treated with TG and left to recover in the absence (yellow) or presence (blue) of NGF are shown following 6 and $20 \mathrm{~h}$ of recovery (g). Data are representative of three separate experiments 
EGF was transient (Supplementary Figure S1). EGF did not stimulate the removal of p17 (Figure 4e), suggesting that sustained ERK activation may be required for its removal. ERK signalling is known to lead to activation of gene transcription. ${ }^{23}$ Pre-treatment with either actinomycin $D$ or cycloheximide inhibited NGF-induced removal of active caspase-3 (Figures $4 \mathrm{f}$ and $\mathrm{g}$ ), indicating the role of gene transcription and protein translation.

Active caspase-3 is not targeted for proteasomal degradation. IAPS have been implicated in ubiquitination and proteasomal degradation of caspase- $3^{24-26}$ although this remains controversial. 8,10 NGF treatment induced an increase in XIAP, clAP1 and clAP2 mRNA levels
(Figure 5a). However, this induction did not correlate with increased clAP1/2 protein levels (Figure 5b) or with increased XIAP in the presence or absence of TG (Figure $5 \mathrm{c}$ ). To further test the role of the IAPs, the SMAC mimetic BV6 was used. BV6 can bind to BIR2 and BIR3 domains of XIAP, inhibiting its ability to bind and antagonize caspases. ${ }^{27}$ BV6 can also bind to clAP1 and clAP2 leading to their auto-ubiquitination and proteasomal degradation. ${ }^{27}$ This can be seen in Figure $5 \mathrm{~d}$, which confirms that BV6 was active in these cells. Although BV6 slightly increased the levels of p17 owing to TG treatment, it did not block the ability of NGF to reduce p17 levels (Figure 5e), suggesting that IAPs do not mediate NGF-induced removal of active caspase-3.
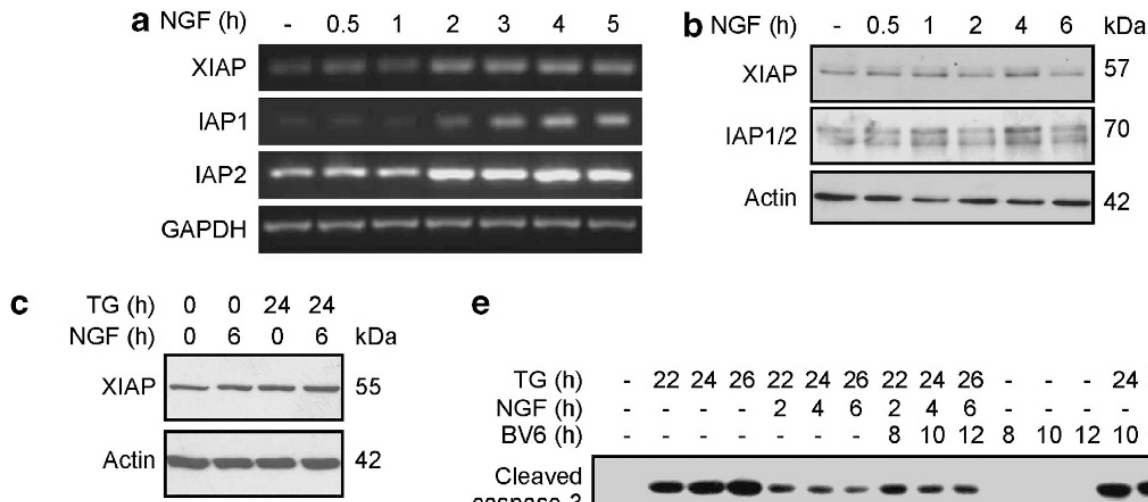

e
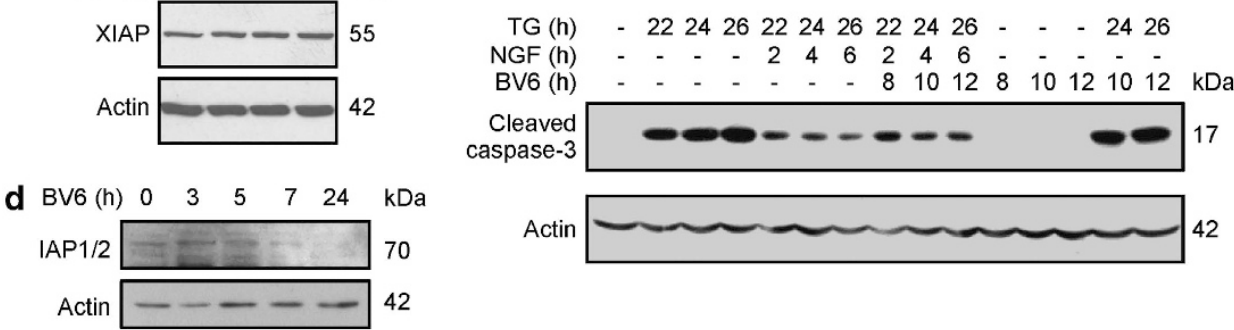

f

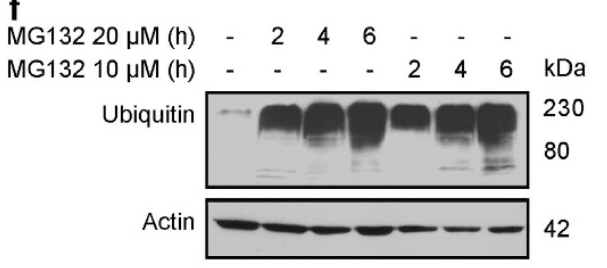

g

TG (h) $\quad-\quad \begin{array}{llllllllll}20 & 22 & 24 & 26 & 22 & 24 & 26 & 22 & 24 & 26\end{array}$

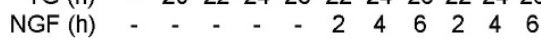

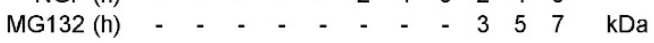

Cleaved
caspase-3

Actin $\square-\ldots-\ldots-\ldots$

h Thapsigargin (h) $\quad-\quad 20222426222426222426$

NGF (h) - $\quad-\quad-\quad-\quad-\quad 2466246$

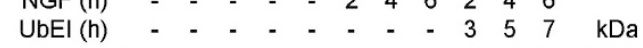

$\begin{aligned} \text { Cleaved } & 17\end{aligned}$

Actin

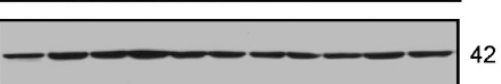

Figure 5 IAPs do not target cleaved caspsase-3 for ubiquitin-proteasome-mediated degradation in NGF-treated cells. PC12 cells were treated with NGF for the indicated times, and changes in the levels of IAPs were analysed. (a) Semi-quantitative reverse transcriptase-PCR was performed to determine XIAP, IAP1 and IAP2 mRNA levels. GAPDH was used as a house-keeping control. (b) Western blotting was used to visualise XIAP and cIAP1/2 protein levels. Actin was used as a loading control. (c) PC12 cells were treated with $1.5 \mu \mathrm{M}$ TG for $18 \mathrm{~h}$ before NGF addition. The cells were harvested at $6 \mathrm{~h}$ after NGF addition, and the protein levels of XIAP were determined using western blotting. Actin was used as a loading control. (d) PC12 cells were treated with $5 \mu \mathrm{M}$ BV6 for the indicated times, and western blotting was performed using anti-IAP1/2 antibody. (e) PC12 cells were treated with $1.5 \mu \mathrm{M}$ TG for $14 \mathrm{~h}$ followed by addition of $5 \mu \mathrm{M} \mathrm{BV} 6$. At $20 \mathrm{~h}$, NGF was added for the indicated times. The cells were harvested for western blotting analysis at 22-26 h as indicated. The 17 subunit levels were analysed using the cleaved caspase-3 antibody. Actin was used as a loading control. Results shown are representative of three distinct experiments. (f) PC12 cells were treated with 10 or $20 \mu \mathrm{M}$ MG132 for the indicated times. The cells were then harvested, and the total levels of ubiquitinated proteins were analysed using an anti-ubiquitin antibody. ( $\mathbf{g}$ and $\mathbf{h}$ ) PC12 cells were treated with $1.5 \mu \mathrm{M}$ TG for $19 \mathrm{~h}$ followed by incubation with $20 \mu \mathrm{M}$ MG132 (g) or $10 \mu \mathrm{M} \mathrm{Ub}$-El (h) for $1 \mathrm{~h}$ before addition of NGF. Cells were harvested at 20-26 h as indicated. The p17 subunit levels were analysed using the cleaved caspase-3 antibody. Actin was used as a loading control. Results shown are representative of three distinct experiments 
We next determined whether the ubiquitin-proteasome degradation machinery is involved. ${ }^{28}$ Proteasome inhibitors MG132 or lactacystin caused an increase in the cellular level of ubiquitinated proteins confirming their activity (Figure 5f, and Supplementary Figure S2). However, neither proteasome inhibitor could abrogate NGF-stimulated removal of p17 (Figure $5 \mathrm{~g}$ and Supplementary Figure S2). In addition, Ub-El, an inhibitor of ubiquitin-activating enzyme $\mathrm{E} 1,{ }^{29}$ had no effect on NGF-induced removal of p17 (Figure 5h). Together, these data indicate a lack of involvement of the ubiquitin-proteasome degradation machinery in NGF-induced degradation of active caspase-3.

NGF induces lysosomal localisation and degradation of p17. Lysosomes are membrane-bound organelles containing acid hydrolases that mediate the degradation of cellular components, including organelles, protein aggregates and specific proteins. ${ }^{30}$ Chloroquine (CQ; a lysosomotropic agent that accumulates within lysosomes and neutralises their acidic interior, thus inhibiting lysosomal enzymes) ${ }^{31}$ caused accumulation of $\mathrm{p} 17$, but not of active caspase-9, in apoptotic cells treated with NGF (Figure 6a). Moreover, $\mathrm{CQ}$ treatment alone did not induce the cleavage of either pro-caspase-3 or -9 (Figure 6a). We also investigated whether antagonism of IAPs would produce an additive effect when used with $C Q$. However, the combination of BV6 and CQ did not have an additive effect on the accumulation of p17 (Supplementary Figure S3b). Interestingly, it was observed that BV6 attenuated the effect of $\mathrm{CQ}$ on p17 levels (Supplementary Figure S3B). Another lysosome inhibitor concanamycin A (ConA), which blocks vacuolar acidification through inhibition of V-type ATPases, ${ }^{32}$ had a less pronounced effect on the level of p17 than $\mathrm{CQ}$, and although NGF-induced loss of cleaved caspase-3 was consistently observed at 2-4 h of NGF treatment, this effect was lost by $6 \mathrm{~h}$ (Figure 6b). This difference in the effect of $C Q$ and ConA could be due to different efficacies of the drugs: $C Q$ caused a more prolonged accumulation of LC3-II compared with ConA and the effect of ConA on LC3-II was no longer evident at $6 \mathrm{~h}$ (Supplementary Figure S3A). Recently, CQ was reported to

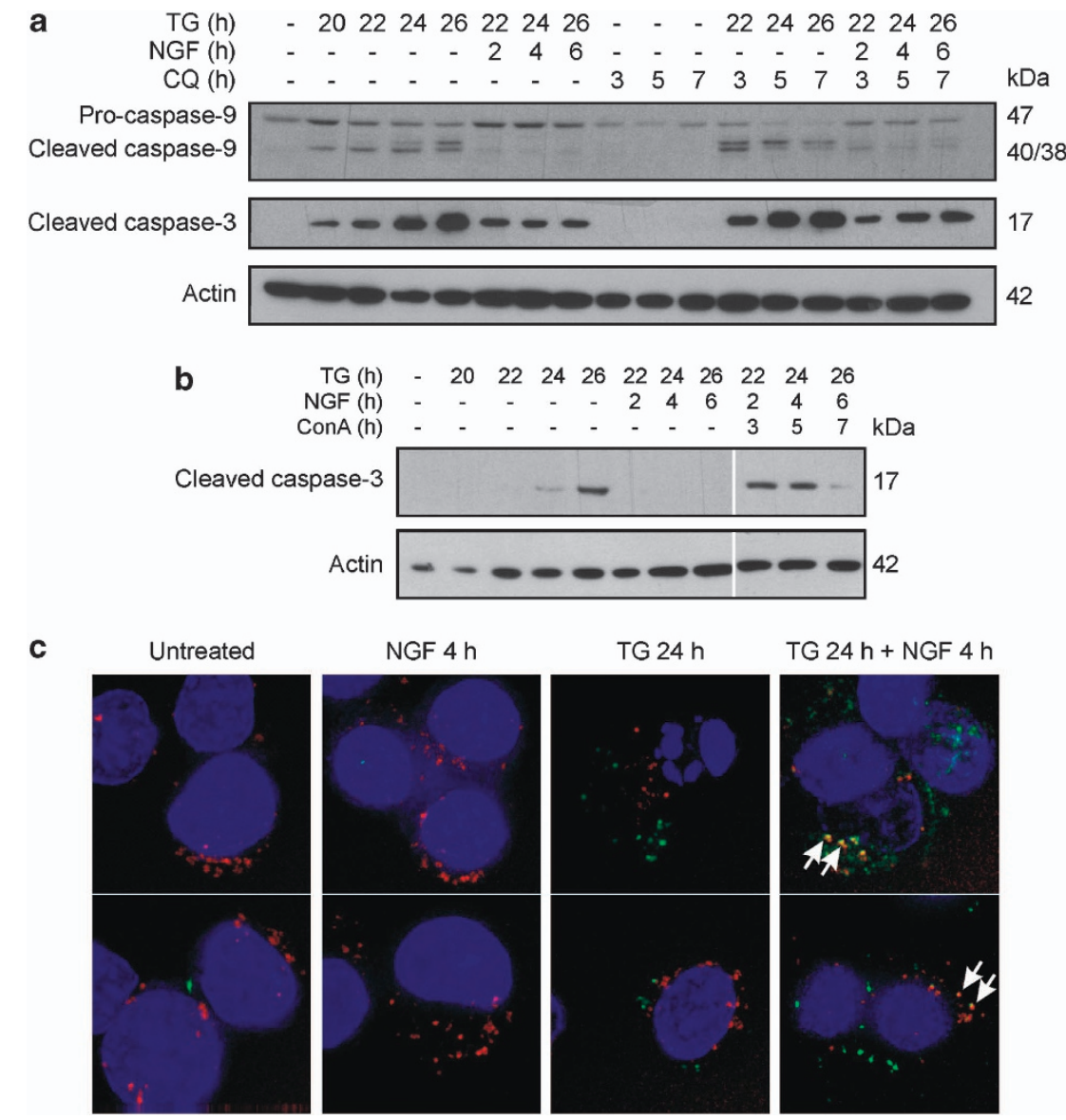

Figure 6 NGF targets cleaved caspase-3 for lysosomal degradation. PC12 cells were treated with $1.5 \mu \mathrm{M} \mathrm{TG}$ for $19 \mathrm{~h}$ followed by treatment with (a) $50 \mu \mathrm{M}$ CQ or (b) $50 \mu \mathrm{M}$ ConA as indicated for $1 \mathrm{~h}$ before addition of NGF. Cells were harvested at $20-26 \mathrm{~h}$. The levels of active caspases were analysed by western blotting using the caspase-9 or cleaved caspase-3 antibodies. Actin was used as a loading control. Results shown are representative of three distinct experiments. (c) PC12 cells were seeded onto eight-well PLL-coated $\mu$-slides (Ibidi) and allowed to adhere overnight. The cells were treated with $1 \mu \mathrm{M}$ TG for $20 \mathrm{~h}$ and then with NGF for a further $3 \mathrm{~h}$. The cells were then stained in normal culture conditions with 1X FAM-DEVD-FMK reagent (green) for $30 \mathrm{~min}$ and then with $50 \mathrm{nM}$ Lysotracker red DND99 (red) for a further 30 min. Hoechst 33342 (blue) was used to visualise the nuclei. The cells were maintained in DMEM and visualised immediately using a DeltaVision core system (Applied Precision). The upper and lower panels show different views of the same samples. Arrows indicate co-staining with Lysotracker and FLICA. Images are representative of three separate experiments 
activate autophagy by inhibiting mTOR, which could contribute to the increase in LC3-II accumulation observed. ${ }^{33}$ Nevertheless, when considered together with the ConA and colocalisation experiments (below), the data support a role for lysosomes in NGF-induced clearance of cleaved caspase-3.

Next, the lysosomal localisation of active caspase-3 was assessed using LysoTracker red to visualize lysosomes in combination with FAM-DEVD-FMK (FLICA; a fluorogenic peptide that binds irreversibly to active caspase-3 and -7 , used to visualize their localisation). In all treatment conditions, cells displayed punctate red fluorescence consistent with distribution of LysoTracker to lysosomes (Figure 6c). FLICA staining was observed in cells treated with $1 \mu \mathrm{M} \mathrm{TG}$, indicating active caspase-3/-7 (Figure 6c). Similarly, TG-treated cells that were exposed to NGF for $4 \mathrm{~h}$ exhibited FLICA staining, some of which was co-localised with lysosomes (Figure 6c). Notably, this co-staining was observed only in cells that were treated with both NGF and TG. Taken together, these data suggest that NGF-induced removal of $p 17$ is dependent on lysosomal degradation of active caspases.

Macroautophagy does not contribute to removal of p17. Lysosomes are the terminal degradative compartment of several pathways, including macroautophagy (a nonselective form of autophagy). ${ }^{30,34}$ We established a stable clone of PC12s with impaired autophagic degradation due to overexpression of functionally inactive Atg4 (dominant negative (DN)-Atg4). ${ }^{35}$ Atg4 is required for conversion of LC3-I to LC3-II during elongation of the isolation membrane, an early step in autophagosome formation. ${ }^{35}$ Neo PC12 cells and DN-Atg4 PC12 cells were treated with $\mathrm{CQ}$ to compare basal autophagic flux. DN-Atg4 PC12 cells exhibited decreased autophagosome formation as judged by reduced LC3-II levels compared with Neo PC12 cells (Figure 7a). Treatment of DN-Atg4 PC12 cells with TG resulted in activation of pro-caspase-3 but to a lesser extent than in parental or Neo PC12 cells (Figure 7b). Nevertheless, NGF treatment induced the removal of cleaved caspase-3 (Figure 7b), suggesting that macroautophagy is not involved in this process.

Lack of requirement for the catalytic activity of caspase-3. It has previously been reported that the catalytic activity of caspase-3 is required for its rapid turnover in HeLa cells and that stabilisation of the active complex with caspase inhibitor abrogated the turnover of active caspase- $3 .{ }^{36}$ Using the pan-caspase inhibitor carbobenzoxy-valyl-alanyl-aspartyl-[Omethyl]-fluoromethylketone (zVAD-fmk), we investigated whether this was also the case for NGF-stimulated removal of $17 .^{36}$ Inhibition of TG-induced DEVDase activity by zVAD-fmk was initially confirmed (Supplementary Figure S4A). However, treatment of PC12 cells with zVAD-fmk before NGF addition did not prevent NGF-dependent removal of p17 (Supplementary Figure S4B), suggesting that the catalytic activity of caspase- 3 is not required for this effect.

Lack of involvement of chaperone-mediated autophagy (CMA). CMA is a form of selective autophagy whereby client proteins are targeted to lysosomes for degradation without the requirement for autophagosome formation. ${ }^{37} \mathrm{CMA}$ client proteins uniquely contain a sequence biochemically related to KFERQ. ${ }^{37}$ The primary sequence of caspase-3 lacks any sequences that fit the requirements for a CMA client, but it does contain a KLFIIQ sequence within the p17 subunit (residues 156-161), which lacks only a required acidic residue (Supplementary Figure S5). As this sequence is next to the enzyme's active site (Supplementary Figure S5), we hypothesized that the cleavage site of caspase substrates (DEVD) could provide the acidic residues that are missing. Therefore, we next examined whether CMA had

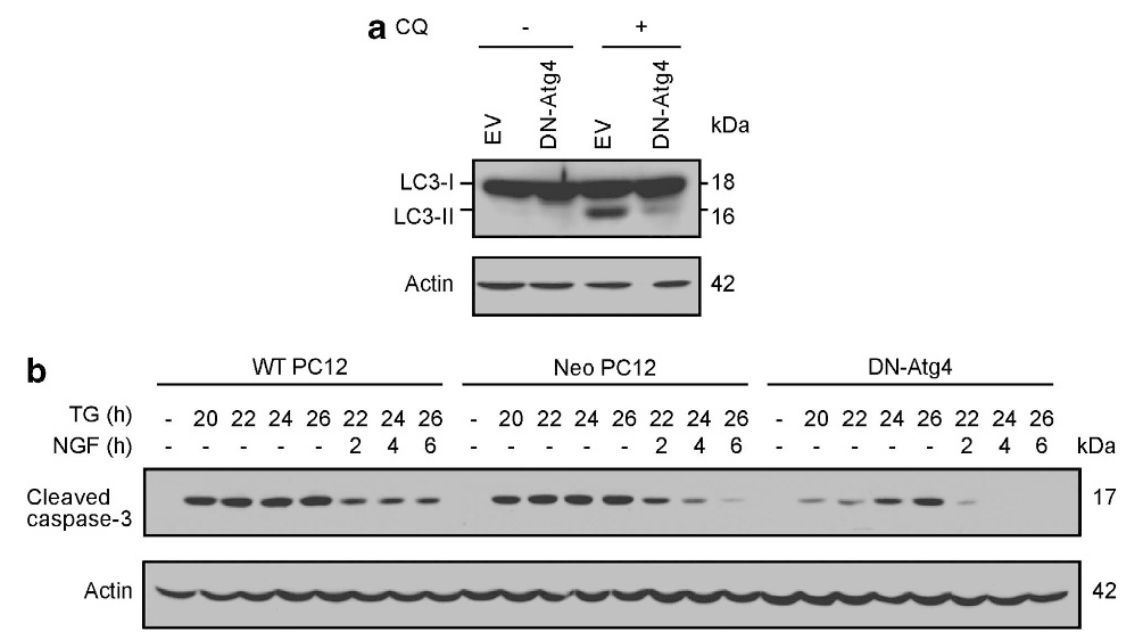

Figure 7 NGF-induced removal of active caspase-3 does not involve macroautophagy. PC12 cells were stably transduced with a lentiviral vector encoding functionally inactive Atg4 (DN-Atg4). (a) PC12 cells were treated with $50 \mu \mathrm{M} \mathrm{CQ}$, and the lipidation state of LC3 protein was analysed by western blotting with anti-LC3 antibody. Actin was used as a loading control. (b) Parental PC12 cells, PC12 cells transduced with empty vector (Neo) and those transduced with DN-Atg4 were treated with $1.5 \mu \mathrm{M}$ TG for $20 \mathrm{~h}$ followed by NGF cells. The cells were harvested at $20-26 \mathrm{~h}$ as indicated, and the levels of the p17 subunit were analysed by western blotting using the cleaved-caspase-3 antibody. Actin was used as a loading control. Images are representative of three independent experiments 
a

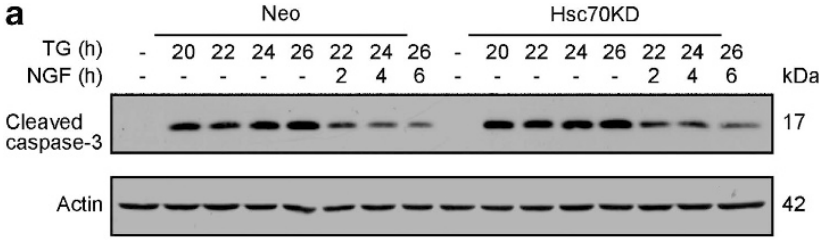

b

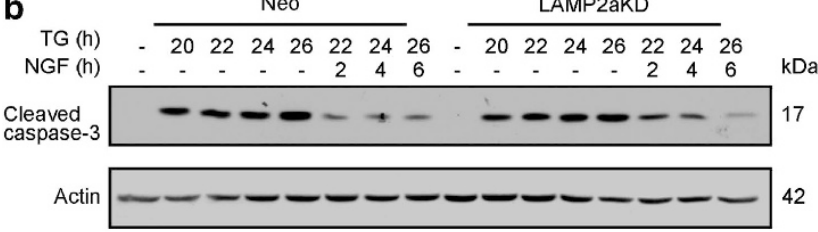

C

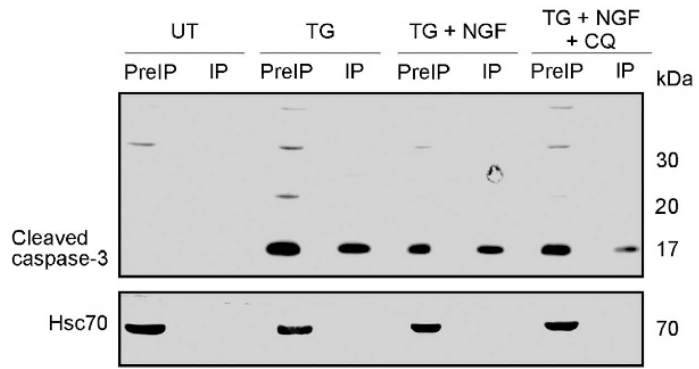

Figure 8 Chaperone-mediated autophagy is not involved in NGF-induced removal of p17. (a and $\mathbf{b}) \mathrm{PC} 12$ cells stably transduced with shRNA to Hsc70 (a) or LAMP2a (b) were treated with $1 \mu \mathrm{M} \mathrm{TG}$ for $20 \mathrm{~h}$ followed by addition of NGF for further 2, 4 and $6 \mathrm{~h}$. The $\mathrm{p} 17$ subunit levels were analysed by western blotting using the cleaved caspase- 3 antibody. Actin was used as a loading control. Results shown are representative of three distinct experiments. (c) PC12 cells were treated with $1 \mu \mathrm{M}$ TG for $19 \mathrm{~h}$ followed by treatment with $25 \mu \mathrm{M}$ CQ for $1 \mathrm{~h}$ before addition of NGF. The cells were then harvested, and the lysate was incubated with cleaved caspase-3 antibody conjugated to Dynal Beads overnight. The beads were then applied to a magnet and washed. The protein was then eluted from the column and the lysate and the immunoprecipitated proteins were analysed by western blotting for p17 (using the cleaved caspase-3 antibody) and Hsc70. The data are representative of three separate experiments

a role in the degradation of $\mathrm{p} 17$. We used shRNA lentiviral constructs to stably knock down (KD) essential proteins in the CMA machinery, heat-shock cognate protein 70 (Hsc70) and lysosome-associated membrane protein type $2 \mathrm{~A}$ (LAMP2A) (Supplementary Figures S6A and B). ${ }^{37} \mathrm{CMA}$ impairment in the generated clones was confirmed by monitoring the accumulation of $\alpha$-synuclein, a known CMA substrate (Supplementary Figure S6C). ${ }^{38}$ In contrast, Hsc70 or LAMP2A KD did not affect NGF-induced removal of p17 (Figures $8 \mathrm{a}$ and b). Furthermore, immunoprecipitation of $\mathrm{p} 17$ did not reveal interaction between p17 and Hsc70 in NGFtreated cells (Figure $8 \mathrm{c}$ ). Together, these data suggest that CMA is not involved in NGF-induced removal of $\mathrm{p} 17$.

\section{Discussion}

It is commonly accepted that the commitment point for apoptosis is MOMP. Here we describe the ability of NGF to protect PC12 cells downstream of MOMP and post-caspase activation via a mechanism that involves the removal of active caspase-3 and requires functional lysosomes.

As most of the data presented were obtained using whole populations of cells, one possible explanation is that
NGF protected that portion of the population that had not yet initiated apoptosis and thus acts upstream of MOMP to reduce further production of active caspases. However, this explanation was ruled out based on two pieces of evidence. First, NGF-stimulated removal of active caspase was dependent on Ras/MAPK and independent of PI3K/Akt signalling. This is in contrast to what we have previously shown for NGF-mediated protection upstream of mitochondria that requires PI3K/Akt and is independent of ERK signalling. ${ }^{13}$ Second, clonogenic survival assays of PS-exposing cells showed that cells treated with NGF displayed greater long-term survival than cells not treated with NGF. Together, these show that NGF can interfere with apoptosis events both upstream and downstream of MOMP via distinct signalling pathways (Supplementary Figure S7). Thus, the effect is not due to reduction in the number of cells initiating apoptosis but rather due to protection downstream of mitochondrial events. This effect is independent of type of apoptotic stimuli. NGFinduced loss of cleaved caspase-3 was observed with a broad range of cytotoxins that activate the mitochondrial apoptosis pathway. The relatively weaker effect with staurosporine might be because it can also inhibit TrkA kinase activity and so may interfere with NGF's protective signalling. ${ }^{39}$

It still remains controversial whether cells can survive following MOMP even if caspases are inhibited and is generally accepted that cells with damaged mitochondria die in a caspase-independent manner if caspase activity is inhibited. $^{1,40}$ However, in sympathetic neurons caspase inhibition (by synthetic caspase inhibitors or XIAP) prevents cell death or significantly extends the commitment to death in cells exhibiting MOMP. ${ }^{41-43}$ In contrast to earlier studies, ${ }^{44}$ recent reports indicate that during apoptosis not all mitochondria undergo MOMP and the persistence of intact mitochondria confers long-term resistance to caspase-independent cell death. ${ }^{45}$ On analysis of the PS-exposing cells, we found that $99 \%$ of the population had undergone MOMP. However, the number of cells which clonogenically survived exceeded the number of cells which had maintained high $\Delta \Psi \mathrm{m}$ and therefore must reflect recovery of the mitochondria. Thus, NGF-stimulated removal of active caspases could allow surviving mitochondria to repopulate the cell and promote long-term survival. ${ }^{45}$

Several reports demonstrate that caspases participate in various non-apoptotic processes, including long-term depression in hippocampal neurons, ${ }^{46}$ sperm maturation, ${ }^{47}$ erythroid differentiation ${ }^{48}$ and axon pruning. ${ }^{49}$ However, the mechanisms which restrict active caspases from causing complete apoptosis are poorly understood. One mechanism includes inhibition of specific caspases by endogenous inhibitors such as XIAP or decoys like cFLIP. ${ }^{10}$ There is some, albeit limited, evidence that the ubiquitin ligase activities of XIAP and clAP1 may target active caspase-3 for proteasomal degradation. ${ }^{24-26}$ In the present study, we investigated this using several different approaches, none of which prevented NGF-stimulated removal of cleaved caspase-3. Although lysosomal inhibition blocked NGF-induced removal of active caspase-3, and active caspase- 3 was co-localised to lysosomes, macroautophagy did not appear to have a role in this effect. This is in contrast to a recent report concerning degradation of initiator caspase-8 via macroautophagy. ${ }^{50}$ 
Moreover, disruption of autophagosome formation with DN-Atg4 did not affect NGF-induced removal of p17. This excludes macroautophagy and also certain forms of selective autophagy such as aggrephagy and chaperone-assisted selective autophagy (which involve ubiquitin-dependent targeting of substrates to autophagosomes that subsequently fuse with lysosomes). ${ }^{51,52}$ In contrast, CMA entails direct delivery of the client protein to the lysosome lumen mediated by $\mathrm{Hsc} 70$ and LAMP2a. $^{37}$ However, experiments to KD these key CMA regulators ruled out CMA in NGF-stimulated degradation of $p 17$.

We propose that protection by NGF is due to a combination of pre- and post-MOMP effects, that is, inhibition of loss of cytochrome $c$ from the mitochondria mediated by PI3K-dependent regulation of BH3-only proteins, ${ }^{13}$ and removal of active caspases by a lysosome-dependent mechanism. Given its importance for certain neuronal subpopulations, it is perhaps unsurprising that NGF stimulates a dual block in the apoptosis pathway that includes careful regulation of caspase activity to prevent inadvertent cell death (Supplementary Figure S7).

These findings could have relevance to the development of therapeutics where there is a need to rescue cells that have already initiated death pathways, such as in stroke or spinal cord injury. ${ }^{1}$ The post-caspase activation activities of NGF may delay the commitment point of apoptosis and thus increase the long-term survival of damaged cells. In fact, NGF has previously been suggested as a possible neuroprotective therapy for Alzheimer's disease. ${ }^{53,54}$ Our data also have relevance to cancer cells, which often display overactive RafMEK-ERK pathways. ${ }^{55,56}$ Sustained ERK signalling by overexpression of $\mathrm{B}-\mathrm{Raf}$ is reported to protect cells from apoptosis downstream of MOMP, ${ }^{57}$ with implications for the resistance of cancer cells to induction of apoptosis. A recent report suggests that cellular recovery from apoptosis is possible at late stages, even after DNA damage has occurred. ${ }^{58}$ However, it has been suggested that cells surviving a transient and reversible apoptotic response acquire permanent genetic changes and undergo oncogenic transformation. ${ }^{58}$ Further understanding of the regulation of active caspases and how this could be exploited to yield new therapeutic strategies is an important goal in combating unwanted apoptosis in degenerative diseases as well as apoptosis resistance in tumour cells.

\footnotetext{
Materials and Methods

Materials. All chemicals were obtained from Sigma-Aldrich (Arklow, Ireland) unless otherwise indicated. Rat adrenal phaeochromocytoma PC12 cells were obtained from European Collection of Cell Cultures (Salisbury, UK). Mouse NGF 2.5S was from Alomone Labs (Jerusalem, Israel). Rabbit polyclonal antibodies against cleaved caspase-3 and actin were purchased from Cell Signalling Technology (Beverly, MA, USA). Two caspase-3 antibodies were purchased from Cell Signalling Technology. The first is the polyclonal total caspase-3 antibody, Cat. No. 9662, that recognises residues surrounding the cleavage site of human caspase-3. The second is the monoclonal cleaved caspase-3 specific antibody, Cat. No 9661, that recognises the amino-terminal residues adjacent to Asp175 of the caspase-3 active site. Anti-XIAP mouse monoclonal and anti-clAP1/2 goat polyclonal antibodies were from Santa Cruz Biotechnologies (Dallas, TX, USA). All secondary antibodies conjugated to horseradish peroxidase were from Jackson ImmunoResearch Laboratories (West Grove, PA, USA). Ac-Asp-Glu-Val-Asp-a-(4-methylcoumaryl-7-amide) (DEVD-MCA) was obtained from Peptide Institute (Osaka, Japan). U0126 was supplied by Calbiochem (Darmstadt, Germany). BV6 was a gift from Genentech (San Francisco, CA, USA).
}

Lysotracker red DND99 and Image-iT LIVE Green Caspase Detection Kits containing FAM-DEVD-FMK reagent were purchased from Invitrogen (Dun Laoghaire, Ireland). Ub-E1 inhibitor was obtained from Biogenova (Rockville, MD, USA).

Cell culture. PC12 cells were cultured in Dulbecco's Modified Eagle's medium (DMEM) supplemented with $5 \%$ heat-inactivated fetal bovine serum, 10\% heat-inactivated horse serum, $50 \mathrm{units} / \mathrm{ml}$ penicillin and $50 \mu \mathrm{g} / \mathrm{ml}$ streptomycin. Cells were seeded at a density of $7 \times 10^{4} \mathrm{cells} / \mathrm{cm}^{2}$ on poly-L-lysine (PLL, $10 \mu \mathrm{g} / \mathrm{ml}$ ) coated plates. Cells were left overnight before treatments. Unless otherwise stated, PC12 cells were incubated with $1.5 \mu \mathrm{M} \mathrm{TG}$ for $20 \mathrm{~h}$ to induce caspase activation followed by treatment with NGF (at $100 \mathrm{ng} / \mathrm{ml}$ ) for up to $6 \mathrm{~h}$ before harvesting.

Flow cytometry analysis of cell death markers. Cells were treated as described and harvested by trypsinisation. For TMRE staining, the cells were incubated with $100 \mathrm{nM}$ TMRE for $30 \mathrm{~min}$ in the dark. Fluorescence was measured at $582 \mathrm{~nm}$ by flow cytomerty. For Annexin V-FITC staining, the cells were centrifuged at $1000 \times g$ for $5 \mathrm{~min}$ and washed once in PBS. The cell pellet was then resuspended in $50 \mu \mathrm{l}$ calcium buffer (10 mM N-2-hydroxyethyl-piperazine- $\mathrm{N}$ 2-ethanesulphonic acid (HEPES) pH 7.5, $140 \mathrm{mM} \mathrm{NaCl}, 2.5 \mathrm{mM} \mathrm{CaCl}_{2}$ ) containing Annexin V-FITC. The cells were then incubated in the dark for $15 \mathrm{~min}$ after which $300 \mu \mathrm{l}$ of calcium buffer was added. Fluorescence was measured at $495 \mathrm{~nm}$ by flow cytometry. All flow cytometric analysis was carried out using the Cyflogic 1.2.1 software (CyFlo Ltd, Turku, Finland).

Western blotting analysis. Following experimental treatments, cells were scraped from the culture flasks and centrifuged at $150 \times \mathrm{g}$ for $5 \mathrm{~min}$ at $4{ }^{\circ} \mathrm{C}$. After washing in PBS, cells were lysed using whole-cell lysis buffer (20 mM HEPES $\mathrm{pH}$ $7.5,350 \mathrm{mM} \mathrm{NaCl}, 1 \mathrm{mM} \mathrm{MgCl}, 0.5 \mathrm{mM}$ EDTA, $0.1 \mathrm{mM}$ ethylene glycol tetraacetic acid (EGTA), 1\% Nonidet P-40 (NP-40), $0.5 \mathrm{mM}$ dithiothreitol (DTT), $0.1 \%$ phenylmethylsulphonyl fluoride (PMSF), $1 \%$ aprotinin, $5 \mathrm{mM} \mathrm{NaF}$ and $1 \mathrm{mM}$ $\mathrm{Na}_{3} \mathrm{VO}_{4}$ ). Cellular debris was centrifuged at $20000 \times g$ for $1 \mathrm{~min}$, and protein content of the supernatant was determined using Bradford reagent with bovine serum albumin (BSA) as the standard.

Forty micrograms of proteins were denatured using Laemmli's sample buffer (62 mM Tris-HCl, pH 6.8, 2\% sodium dodecyl sulphate (SDS), 5\% $\beta$-mercaptoethanol, $4 \%$ glycerol, $1 \mathrm{mM}$ PMSF, $0.01 \%$ bromophenol blue) and boiled at $95^{\circ} \mathrm{C}$ for $5 \mathrm{~min}$. Proteins were separated by SDS-polyacrylamide gel electrophoresis and transferred onto nitrocellulose membranes (Whatman, GE Healthcare Life Sciences, Buckinghamshire, UK). Membranes were probed with antibodies $(1: 1000)$ overnight at $4{ }^{\circ} \mathrm{C}$ followed by appropriate HRP-conjugated secondary antibody. Protein bands were visualised using Immobilon Western Chemiluminescent HRP substrate (Millipore, Darmstadt, Germany).

Detection of DEVDase activity. The activity of caspase-3-like enzymes (DEVDase activity) was determined fluorometrically as reported previously. ${ }^{59}$ Briefly, cells were scraped and centrifuged at $300 \times g$ at $4{ }^{\circ} \mathrm{C}$ for $5 \mathrm{~min}$. Pellets were washed in ice-cold PBS, re-suspended in PBS and then flash-frozen in liquid nitrogen. Fifty micromoles of DEVDase-substrate (DEVD-MCA) in reaction buffer (100 mM HEPES pH 7.5, 10\% sucrose, 0.1\% 3-[(3-cholamidopropyl)-dimethylammonio]-1-propanesulfonate, $5 \mathrm{mM}$ DTT, $0.01 \% \mathrm{NP}-40$ ) was added to the lysates. The release of free AMC was monitored at $37^{\circ} \mathrm{C}$ at 60 -s intervals over a 30-min period using a Wallac Victor multilabel counter (Perkin Elmer, Ballymount, Ireland) (excitation $355 \mathrm{~nm}$, emission $460 \mathrm{~nm}$ ). Fluorescent units were converted to nanomoles of AMC released per minute per mg of enzyme using a standard curve generated with free AMC and subsequently related to protein concentration.

Clonogenic assay. Following treatments with TG and NGF, cells were reseeded into $78-\mathrm{cm}^{2}$ dishes at a density of $7.8 \times 10^{2} \mathrm{cells} / \mathrm{cm}^{2}$ and allowed to proliferate for 14 days. Colonies were fixed and stained with $0.25 \%$ methylene blue in $50 \%$ ethanol/50\% distilled water for 30 min and then rinsed with $\mathrm{dH}_{2} \mathrm{O}$. Colonies containing $>50$ cells were counted.

Determination of long-term cell survival of PS-exposing PC12 cells. Cells exposing PS on the outer leaflet of the plasma membrane were separated from the rest of the cell population using the Annexin V MicroBead Kit (Miltenyi Biotec Headquarters, Surrey, UK). Following treatment with $1 \mu \mathrm{M} \mathrm{TG}$ for $20 \mathrm{~h}, \mathrm{PC} 12$ cells were trypsinised and resuspended in magnetic Annexin V 
MicroBeads as per the manufacturer's instructions. The cells were then applied to the Miltenyi Biotec MS MACS column and placed in a magnetic field to allow cells exposing PS to bind to the magnetic Annexin V beads. The beads were washed to remove any unlabeled cells, and the MS MACS column was removed from the magnetic field. The magnetically labelled PS-exposing cells were eluted and were divided evenly into two $1.9-\mathrm{cm}^{2}$ dishes. This experiment was repeated six times and a range of 850-10 000 cells were seeded. One dish was treated with $100 \mathrm{ng} / \mathrm{ml}$ NGF every second day, and the other was left untreated. Prolonged treatment of PC12 cells with NGF causes them to differentiate and extend neurites. ${ }^{17}$ Therefore, to assess long-term survival of the cells, the numbers of surviving colonies (defined as colonies containing $>10$ cells on untreated plates and cells that had extended neurites that were longer than twice the diameter of the cell body on the NGF-treated plates) were counted after 7 days. On the NGF-treated plates, the number of cell colonies plus cells with neurites (longer than twice the diameter of the cell body), which indicate surviving cells, was expressed as the fold change relative to the number of cell colonies that were present on the untreated plate.

Immunofluorescence of cleaved caspase-3. PC12 cells were treated as described and cytospun at 200 r.p.m. for 5 min onto PLL-coated microscope slides. The cells were then washed in PBS and fixed in $4 \%$ paraformaldehyde for $20 \mathrm{~min}$. The cells were then permeabilised using $0.2 \%$ Triton X-100 for $5 \mathrm{~min}$. After washing the cells in washing buffer (1\% BSA in $0.05 \%$ PBS-Tween), the cells were blocked for 30 min with $3 \%$ goat serum and $1 \%$ BSA in $0.05 \%$ PBS-Tween. Then a 1/200 dilution of cleaved caspase-3-specific antibody was incubated with the cells overnight at $4{ }^{\circ} \mathrm{C}$. The antibody was then removed, and the cells were washed $3 \times 5$-min washes with rocking. A 1/1000 dilution of anti-rabbit Alexa Fluor 488 was then incubated with the cells for $1 \mathrm{~h}$ at room temperature. The secondary antibody was removed, and the cells were washed $3 \times 5$-min washes with rocking The cells were then mounted in VECTASHIELD (Vector Laboratories Ltd, Peterborough, UK) mounting media containing DAPI and visualised using the DeltaVision core system (Applied Precision, GE Healthcare Life Sciences), which controlled an interline charge-coupled device camera (coolsnap HQ2; Roper Scientific, Martinsried, Germany) mounted on an inverted microscope (1X-71; Olympus, Southend-on-Sea, UK). Images were collected using a $\times 60$ oil objective at $0.2-\mu \mathrm{m} z$ sections. All images were deconvolved and maximum intensity was projected using the SoftWoRx software programme (Applied Precision).

RNA extraction and RT-PCR. Poly(A) + RNA extraction from cells was performed according to the protocol for the Total mammalian RNA extraction kit (Sigma-Aldrich). Reverse transcription was carried out with $2 \mu \mathrm{g}$ total RNA and oligo(dT) (Invitrogen) using 20 U Superscript II Reverse Transcriptase (Invitrogen). cDNAs for genes of interest were amplified during 33 cycles with the following primers: XIAP 5'-primer (5'-GACAGGCCGTCGGAGACTC-3'); XIAP 3'-primer (5'-GTGCTCTGACCAGGCACGG-3'); IAP1 $5^{\prime}$-primer (5'-TGGCTACTTCAGTGG CTCCT-3'); IAP1 $3^{\prime}$-primer (3'-GCAGGCCACTCTATCTCCAG-5'); IAP2 5'-primer (5'-GCCCTCTTAATTCTAGAGCAG-3'); IAP2 3'-primer (5'-ACATCTCAAGCCAC CATCACA-3'); GAPDH $\quad 5^{\prime}$-primer (5'-ACCACAGTCCATGCCATC-3'); and GAPDH $3^{\prime}$-primer (5'-TCCACCACCCTGTTGCTG-3'). GAPDH was used as an endogenous control.

Fluorescence microscopy. Cells were seeded onto eight-well PLL-coated $\mu$-slides (lbidi, Martinsried, Germany) at a seeding density of $3.5 \times 10^{4} / \mathrm{cm}^{2}$. The cells were treated with $1 \mu \mathrm{M}$ TG for $20 \mathrm{~h}$ followed by treatment with $100 \mathrm{ng} / \mathrm{ml} \mathrm{NGF}$ for $3 \mathrm{~h}$. The 1X FAM-DEVD-FMK reagent (from the Image-iT LIVE Green Caspase Detection Kit) was added for $1 \mathrm{~h}$, along with $50 \mathrm{nM}$ Lysotracker red DND99 for the final $0.5 \mathrm{~h}$. Four hours after NGF treatment, the cells were washed with DMEM. The nuclei were stained using $1 \mathrm{nM}$ Hoechst 33258 for $5 \mathrm{~min}$ after which the cells were washed twice with $1 \mathrm{X}$ apoptosis wash buffer (from the Image-iT LIVE Green Caspase Detection Kit). The cells were maintained in DMEM and visualised immediately using a DeltaVision core system (Applied Precision), which controlled an interline charge-coupled device camera (coolsnap HQ2; Roper Scientific) mounted on an inverted microscope (1X-71; Olympus). Images were collected using a $\times 100$ oil objective at $0.2-\mu \mathrm{m} z$ sections. All images were deconvolved, and maximum intensity was projected using the SoftWoRx software programme (Applied Precision).

Plasmids. ATG4B(C74A) cDNA was cloned from an expression plasmid encoding mStrawberry (Addgene, Cambridge, UK) into the lentiviral vector pWPT
(Addgene) in which the GFP was removed. To amplify the mStrawberryATG4B (C74A) sequence from the expression vector, the primers were designed with a mlul restriction site sequence in the forward primer $5^{\prime}$-CGCGTATGGT GAGCAAGGGCCGAGGAG-3' and sall restriction site in the reverse primer $5^{\prime}$-GTCGACTCAGAGGGATAAGATTTCAAAGTC- $3^{\prime}$. The PCR product was ligated into a TA-TOPO vector (Invitrogen). Both the TA-TOPO vector containing PCR product and the pWPT vector were digested with restriction enzymes mlul and Sall. T4 DNA ligase (NEB) was used to ligate the mStrawberry-ATG4B(C74A) insert into the pWPT vector to generate pWPT-mStrawberry-ATG4B(C74A) lentiviral vector named DN-Atg4. Mouse GIPZ lentiviral shRNAmiR individual clones V2LMM_15767 and V3LMM_429629 (Open Biosystems, Thermo Scientific, Dublin, Ireland) were used to evaluate the functional effects of silencing of Hsc70 and LAMP2a, respectively. The plasmid expressing human $\alpha$-synuclein under the synapsin promoter was a kind gift from Dr. Eilís Dowd, National University of Ireland, Galway, Ireland.

Transient transfection of PC12 cells. PC12 cells were seeded at a density of $3.5 \times 10^{4} \mathrm{cell} / \mathrm{s} / \mathrm{cm}^{2}$ into a $10-\mathrm{cm}$ dish and allowed to recover overnight. The cells were then transfected with $2 \mu \mathrm{g}$ of plasmid DNA using Lipofectamine 2000 transfection reagent (Invitrogen) and a DNA to lipid ratio of $1: 2.5$. The media was removed $6 \mathrm{~h}$ after transfection. Typical transfection efficiency was $\sim 60 \%$.

Generation of stable PC12 cell lines by lentiviral infection. Lentivirus was made by transfection of plasmid constructs along with a secondgeneration lentivirus packaging system (pMD2.G, pAX2 and pRSC-Rev from Addgene) into HEK293T cells using JET PEI transfection reagent (Polyplus Transfection, Illkirch, France). Transduction efficiency of DN-Atg4 construct was $>90 \%$ and was monitored by fluorescence microscopy and quantified by flow cytometry analysis using mStrawberry fluorescent tag as a marker for transduced cells. Stable cell lines containing LAMP2a and Hsc70 shRNA constructs were selected with $0.5 \mu \mathrm{g} / \mathrm{ml}$ puromycin (Sigma-Aldrich) for 1 week. The transduction efficiency was $>70 \%$ as judged by fluorescence microscopy using GFP as a marker for transduced cells.

Immunoprecipitation of cleaved caspase-3. Cells were seeded into $75-\mathrm{cm}^{2}$ flasks at a seeding density of $3.5 \times 10^{4} / \mathrm{cm}^{2}$. Following experimental treatments, cells were scraped from the culture flasks and centrifuged at $150 \times g$ for $5 \mathrm{~min}$ at $4{ }^{\circ} \mathrm{C}$. The cells were then washed in ice-cold PBS and lysed using the lysis buffer (20 mM Tris (pH 7.5), $150 \mathrm{mM} \mathrm{NaCl}, 1 \mathrm{mM}$ EGTA, $1 \% \mathrm{NP}-40$ ) containing EDTA-free protease inhibitor cocktail tablet (Invitrogen). The lysate was the centrifuged at 14000 r.p.m. for $10 \mathrm{~min}$, and the supernatant was incubated with $1.5 \mathrm{mg}$ of preprepared Dynal beads (Invitrogen). The Dynal beads were prepared as per the manufacture's guidelines and conjugated overnight with a $1 / 100$ dilution of cleaved-caspase- 3 antibody at $37^{\circ} \mathrm{C}$. The lysates were incubated with the conjugated beads for $12 \mathrm{~h}$ at $4^{\circ} \mathrm{C}$. Then the beads were collected by magnetic separation, the supernatant was removed and the beads were washed four times in lysis buffer. The beads were then resuspended in $40 \mu \mathrm{l}$ of elution buffer for $5 \mathrm{~min}$ at room temperature and collected by magnetic separation. The eluate was removed and subjected to western blotting for cleaved caspase-3 and $\mathrm{Hsc70.}$

Statistical analysis. Statistical analysis was carried out using the SPSS software (IBM, Dublin, Ireland). Values are expressed as means \pm S.E.M. of at least three separate experiments. All data were analysed using the repeatedmeasures ANOVA followed by LSD or Bonferroni multiple comparisons post hoc tests as indicated. Differences were considered statistically significant at $P<0.05$.

\section{Conflict of Interest}

The authors declare no conflict of interest.

Acknowledgements. We are grateful to Genentech for providing BV6 reagent. We acknowledge the assistance of Dr. Shane Deegan in making stable DN-Atg4-expressing PC12 cells. We also acknowledge past and present members of the Apoptosis Research Centre for helpful discussions. This material is based upon works supported by the Science Foundation Ireland under Grant No. 09/RFP/ BMT2153. This work was also supported by the Irish Research Council for 
Science, Engineering and Technology (EMBARK scholarships to KM and EK), research funding from Breast Cancer Campaign, UK (Grant number 2008NovPhD21), the Thomas Crawford Hayes fund, School of Natural Sciences, NUI Galway, Ireland and the Beckman fund, School of Natural Sciences, NUI Galway, Ireland.

1. Galluzzi L, Morselli E, Kepp $O$, Kroemer G. Targeting post-mitochondrial effectors of apoptosis for neuroprotection. Biochim Biophys Acta. 2009; 1787: 402-413.

2. Taylor RC, Cullen SP, Martin SJ. Apoptosis: controlled demolition at the cellular level. Nat Rev Mol Cell Biol 2008; 9: 231-241.

3. Tait SW, Green DR. Mitochondria and cell death: outer membrane permeabilization and beyond. Nat Rev Mol Cell Biol 2010; 11: 621-632.

4. Zou H, Li Y, Liu X, Wang X. An APAF-1.cytochrome c multimeric complex is a functional apoptosome that activates procaspase-9. J Biol Chem 1999; 274: 11549-11556.

5. Slee EA, Adrain C, Martin SJ. Serial killers: ordering caspase activation in apoptosis. Cell Death Differ 1999; 6: 1067-1074.

6. Cory S, Adams JM. The Bcl2 family: regulators of the cellular life-or-death switch. Nat Rev Cancer 2002; 2: 647-656.

7. Kutuk $\mathrm{O}$, Letai $\mathrm{A}$. Regulation of $\mathrm{Bcl}-2$ family proteins by posttranslational modifications. Curr Mol Med 2008; 8: 102-118.

8. Galban S, Duckett CS. XIAP as a ubiquitin ligase in cellular signaling. Cell Death Differ 2010; 17: 54-60.

9. Eckelman BP, Salvesen GS, Scott FL. Human inhibitor of apoptosis proteins: why XIAP is the black sheep of the family. EMBO Rep 2006; 7: 988-994.

10. Pop C, Salvesen GS. Human caspases: activation, specificity, and regulation. J Biol Chem 2009; 284: 21777-21781.

11. Huang EJ, Reichardt LF. Neurotrophins: roles in neuronal development and function. Annu Rev Neurosci 2001; 24: 677-736.

12. Deshmukh M, Johnson Jr EM. Programmed cell death in neurons: focus on the pathway of nerve growth factor deprivation-induced death of sympathetic neurons. Mol Pharmacol 1997; 51: 897-906

13. Szegezdi E, Herbert KR, Kavanagh ET, Samali A, Gorman AM. Nerve growth factor blocks thapsigargin-induced apoptosis at the level of the mitochondrion via regulation of Bim. J Cell Mol Med 2008; 12: 2482-2496.

14. Martin SJ, Finucane DM, Amarante-Mendes GP, O'Brien GA, Green DR. Phosphatidylserine externalization during CD95-induced apoptosis of cells and cytoplasts requires ICE/CED-3 protease activity. J Biol Chem 1996; 271: 28753-28756.

15. Suzuki J, Denning DP, Imanishi E, Horvitz HR, Nagata S. Xk-related protein 8 and CED-8 promote phosphatidylserine exposure in apoptotic cells. Science 2013; 341: 403-406.

16. Lee SH, Meng XW, Flatten KS, Loegering DA, Kaufmann SH. Phosphatidylserine exposure during apoptosis reflects bidirectional trafficking between plasma membrane and cytoplasm. Cell Death Differ 2013; 20: 64-76.

17. Greene LA, Tischler AS. Establishment of a noradrenergic clonal line of rat adrenal pheochromocytoma cells which respond to nerve growth factor. Proc Natl Acad Sci USA 1976; 73: 2424-2428.

18. Balasubramanian K, Mirnikjoo B, Schroit AJ. Regulated externalization of phosphatidylserine at the cell surface: implications for apoptosis. J Biol Chem 2007; 282: 18357-18364.

19. Angeles TS, Yang SX, Steffler C, Dionne CA. Kinetics of trkA tyrosine kinase activity and inhibition by K-252a. Arch Biochem Biophys 1998; 349: 267-274.

20. Yao R, Cooper GM. Requirement for phosphatidylinositol-3 kinase in the prevention of apoptosis by nerve growth factor. Science 1995; 267: 2003-2006.

21. Xue L, Murray JH, Tolkovsky AM. The Ras/phosphatidylinositol 3-kinase and Ras/ERK pathways function as independent survival modules each of which inhibits a distinct apoptotic signaling pathway in sympathetic neurons. J Biol Chem 2000; 275 : 8817-8824.

22. Huff $\mathrm{K}$, End $\mathrm{D}$, Guroff $\mathrm{G}$. Nerve growth factor-induced alteration in the response of $\mathrm{PC} 12$ pheochromocytoma cells to epidermal growth factor. J Cell Biol 1981; 88: 189-198.

23. Murphy LO, Mackeigan JP, Blenis J. A network of immediate early gene products propagates subtle differences in mitogen-activated protein kinase signal amplitude and duration. Mol Cell Biol 2004; 24: 144-153.

24. Schile AJ, Garcia-Fernandez M, Steller H. Regulation of apoptosis by XIAP ubiquitin-ligase activity. Genes Dev 2008; 22: 2256-2266.

25. Choi YE, Butterworth M, Malladi S, Duckett CS, Cohen GM, Bratton SB. The E3 ubiquitin ligase cIAP1 binds and ubiquitinates caspase- 3 and -7 via unique mechanisms at distinct steps in their processing. J Biol Chem 2009; 284: 12772-12782.

26. Suzuki $Y$, Nakabayashi $Y$, Takahashi R. Ubiquitin-protein ligase activity of $X$-linked inhibitor of apoptosis protein promotes proteasomal degradation of caspase-3 and enhances its anti-apoptotic effect in Fas-induced cell death. Proc Natl Acad Sci USA 2001; 98: 8662-8667.

27. Varfolomeev E, Blankenship JW, Wayson SM, Fedorova AV, Kayagaki N, Garg P et al. IAP antagonists induce autoubiquitination of C-IAPs, NF-kappaB activation, and TNFalphadependent apoptosis. Cell 2007; 131: 669-681.
28. Chen L, Smith L, Wang Z, Smith JB. Preservation of caspase-3 subunits from degradation contributes to apoptosis evoked by lactacystin: any single lysine or lysine pair of the small subunit is sufficient for ubiquitination. Mol Pharmacol 2003; 64: 334-345.

29. Yang Y, Kitagaki J, Dai RM, Tsai YC, Lorick KL, Ludwig RL et al. Inhibitors of ubiquitinactivating enzyme (E1), a new class of potential cancer therapeutics. Cancer Res 2007; 67: 9472-9481.

30. Pryor PR, Luzio JP. Delivery of endocytosed membrane proteins to the lysosome. Biochim Biophys Acta 2009; 1793: 615-624.

31. Ohkuma S, Poole B. Fluorescence probe measurement of the intralysosomal pH in living cells and the perturbation of $\mathrm{pH}$ by various agents. Proc Natl Acad Sci USA 1978; 75: 3327-3331.

32. Woo JT, Shinohara C, Sakai K, Hasumi K, Endo A. Isolation, characterization and biological activities of concanamycins as inhibitors of lysosomal acidification. $J$ Antibiot (Tokyo) 1992; 45: 1108-1116.

33. Musiwaro P, Smith M, Manifava M, Walker SA, Ktistakis NT. Characteristics and requirements of basal autophagy in HEK 293 cells. Autophagy 2013; 9: 1407-1417.

34. Levine B, Kroemer G. Autophagy in the pathogenesis of disease. Cell 2008; 132 : $27-42$.

35. Fujita N, Hayashi-Nishino M, Fukumoto H, Omori H, Yamamoto A, Noda T et al. An Atg4B mutant hampers the lipidation of LC3 paralogues and causes defects in autophagosome closure. Mol Biol Cell 2008; 19: 4651-4659.

36. Tawa P, Hell K, Giroux A, Grimm E, Han Y, Nicholson DW et al. Catalytic activity of caspase-3 is required for its degradation: stabilization of the active complex by synthetic inhibitors. Cell Death Differ 2004; 11: 439-447.

37. Kaushik S, Bandyopadhyay U, Sridhar S, Kiffin R, Martinez-Vicente M, Kon $M$ et al. Chaperone-mediated autophagy at a glance. J Cell Sci 2011; 124: 495-499.

38. Cuervo AM, Stefanis L, Fredenburg R, Lansbury PT, Sulzer D. Impaired degradation of mutant alpha-synuclein by chaperone-mediated autophagy. Science 2004; 305: 1292-1295.

39. Ohmichi M, Decker SJ, Pang L, Saltiel AR. Inhibition of the cellular actions of nerve growth factor by staurosporine and $\mathrm{K} 252 \mathrm{~A}$ results from the attenuation of the activity of the trk tyrosine kinase. Biochemistry 1992; 31: 4034-4039.

40. Tait SW, Green DR. Caspase-independent cell death: leaving the set without the final cut. Oncogene 2008; 27: 6452-6461.

41. Deshmukh M, Kuida K, Johnson Jr EM. Caspase inhibition extends the commitment to neuronal death beyond cytochrome $\mathrm{c}$ release to the point of mitochondrial depolarization. $J$ Cell Biol 2000; 150: 131-143.

42. Potts PR, Singh S, Knezek M, Thompson CB, Deshmukh M. Critical function of endogenous XIAP in regulating caspase activation during sympathetic neuronal apoptosis. J Cell Biol 2003; 163: 789-799.

43. Martinou I, Desagher S, Eskes R, Antonsson B, Andre E, Fakan S et al. The release of cytochrome $\mathrm{c}$ from mitochondria during apoptosis of NGF-deprived sympathetic neurons is a reversible event. J Cell Biol 1999; 144: 883-889.

44. Goldstein JC, Waterhouse NJ, Juin P, Evan Gl, Green DR. The coordinate release of cytochrome $\mathrm{c}$ during apoptosis is rapid, complete and kinetically invariant. Nat Cell Biol 2000; 2: 156-162.

45. Tait SW, Parsons MJ, Llambi F, Bouchier-Hayes L, Connell S, Munoz-Pinedo C et al. Resistance to caspase-independent cell death requires persistence of intact mitochondria. Dev Cell 2010; 18: 802-813.

46. Li Z, Jo J, Jia JM, Lo SC, Whitcomb DJ, Jiao S et al. Caspase-3 activation via mitochondria is required for long-term depression and AMPA receptor internalization. Cell 2010; 141: 859-871.

47. Arama E, Agapite J, Steller H. Caspase activity and a specific cytochrome $\mathrm{C}$ are required for sperm differentiation in Drosophila. Dev Cell 2003; 4: 687-697.

48. Boehm D, Mazurier C, Giarratana MC, Darghouth D, Faussat AM, Harmand L et al. Caspase-3 is involved in the signalling in erythroid differentiation by targeting late progenitors. PLoS One 2013; 8: e62303.

49. Cusack CL, Swahari V, Hampton Henley W, Michael Ramsey J, Deshmukh M. Distinct pathways mediate axon degeneration during apoptosis and axon-specific pruning. Nat Commun 2013; 4: 1876.

50. Hou W, Han J, Lu C, Goldstein LA, Rabinowich H. Autophagic degradation of active caspase-8: a crosstalk mechanism between autophagy and apoptosis. Autophagy 2010; 6 : $891-900$.

51. Lamark $T$, Johansen T. Aggrephagy: selective disposal of protein aggregates by macroautophagy. Int J Cell Biol 2012; 2012: 736905.

52. Arndt V, Dick N, Tawo R, Dreiseidler M, Wenzel D, Hesse M et al. Chaperoneassisted selective autophagy is essential for muscle maintenance. Curr Biol 2010; 20: 143-148.

53. Tuszynski MH, Thal L, Pay M, Salmon DP, U HS, Bakay R et al. A phase 1 clinical trial of nerve growth factor gene therapy for Alzheimer disease. Nat Med 2005; 11 : $551-555$.

54. Weissmiller AM, Wu C. Current advances in using neurotrophic factors to treat neurodegenerative disorders. Transl Neurodegener 2012; 1: 14. 
55. Roberts PJ, Der CJ. Targeting the Raf-MEK-ERK mitogen-activated protein kinase cascade for the treatment of cancer. Oncogene 2007; 26: 3291-3310.

56. Little AS, Smith PD, Cook SJ. Mechanisms of acquired resistance to ERK1/2 pathway inhibitors. Oncogene 2013; 32: 1207-1215.

57. Erhardt $P$, Schremser EJ, Cooper GM. B-Raf inhibits programmed cell death downstream of cytochrome $\mathrm{c}$ release from mitochondria by activating the MEK/Erk pathway. $\mathrm{Mol} \mathrm{Cell}$ Biol 1999; 19: 5308-5315.

58. Tang HL, Tang HM, Mak KH, Hu S, Wang SS, Wong KM et al. Cell survival, DNA damage, and oncogenic transformation after a transient and reversible apoptotic response. Mol Bio Cell 2012; 23: 2240-2252.

59. Gorman AM, Bonfoco E, Zhivotovsky B, Orrenius S, Ceccatelli S. Cytochrome c release and caspase-3 activation during colchicine-induced apoptosis of cerebellar granule cells. Eur J Neurosci 1999; 11: 1067-1072.
Cell Death and Disease is an open-access journal published by Nature Publishing Group. This work is licensed under a Creative Commons Attribution-NonCommercialNoDerivs 3.0 Unported License. The images or other third party material in this article are included in the article's Creative Commons license, unless indicated otherwise in the credit line; if the material is not included under the Creative Commons license, users will need to obtain permission from the license holder to reproduce the material. To view a copy of this license, visit http://creativecommons.org/licenses/ by-nc-nd/3.0/

Supplementary Information accompanies this paper on Cell Death and Disease website (http://www.nature.com/cddis) 